designers in Britain and he is in close touch with the President of the Board of Trade and trying to find ways to ameliorate the position. The Department of Scientific and Industrial Research at present employs 170 scientists in Scotland, and it is intended to increase this number, subject to assessments of changing priorities and the resources available. There are about 22,000 members of research associations, of whom a few belong to more than one association. British plans for space exploration do not include projects for sending mon into space.

\section{U.K. Expenditure on Science, Technology and Education}

Is a written answer in the House of Commons on November 28, the Parliamentary Secretary for Science, Mr. Denzil Freeth, said that the greater part of the expenditure on scientific and technological research in universities, estimated at $£ 23 \cdot 3$ million in $1958-59$ and $£ 25.9$ million in $1959-60$, was met from the recurrent grants made by the Treasury on the recommendation of the University Grants Committee and was not separately identified. Research Council grants to universities and to researeh units and institutes associated with universities amounted to $£ 3.1$ million in $1957-58, £ 3.5$ million in $1958-59, £ 4.5$ million in $1959-60, £ 6$ million in $1960-61$ and $£ 8.2$ million in 1961-62. In figures circulated for the Research Councils, with the exception of the Overseas Research Council, the grants from the Depart. ment of Scientific and Industrial Research are given as $£ 1,315,000$ in studentships and fellowships and $£ 2,600,000$ in research grants for $1961-62$, the corresponding figures for $1960-61$ being $£ 1,050,000$ and $£ 1,490,000$. For the Agricultural Research Couneil in 1961-62, studentships and fellowships amounted to $\$ 31,000$, research grants to $£ 157,000$, exponditure of research units within universities $£ 273,000$ and grants to research units or institutes associated with universities, $£ 1,011,000$; for the period 1960-61, the figures are $£ 24,000, £ 104,000, £ 299,000$, and $£ 931,000$. For the Medical Research Council the corresponding figures are $£ 115,000, £ 811,000$, $£ 1,526,000$, and $£ 317,000$ in $1961-62$, and $£ 100,000$, $£ 620,000$, £1, 060,000 and $£ 285,000$ in $1960-61$. For the Nature Conservancy, they are $£ 21,000, £ 20,000$, $£ 11,000$ under the first three headings in 1961-62, and $£ 18,000$, $£ 11,000$ and $£ 7,000$ in $1960-61$.

Replying to a question in the House of Commons on November 30, the Minister of Education, Sir David Eccles, said that the Ministry's present grant to the National Foundation for Educational Research was $£ 7,000$ and local education authorities were con-

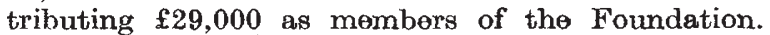
The Ministry was at present in discussion with the Foundation, and Sir David undertook to see that the availability of information was included.

\section{Toxic Chemicals in Agriculture}

ON December 5, the Joint Parliamentary Secretary to the Ministry of Agriculture, Fishories and Food, Earl Waldegrave, announced publication of the report of the Research Study Group on Toxic Chemicals in Agriculture and Food Storage. $\mathrm{He}$ said that the report concluded that protective measures now in force are generally successful, but affirmed the need for more fundamental and applied research in this field. Earl Waldegrave said that the Government accepted the conclusions and intends to implement the Group's recommendations to the full extent of the additional resources which can be made available. The Minister, Mr. C. Soames, made a similar statement in a written answer in the House of Commons on the same day, but, when pressed, neither he nor Earl Waldegrave would add to that statement. In reply to further questions on December 7, Mr. Soames said that he would be replying next week to the Select Committee on Estimates, which, in its Sixth Report of June 28, had recommended an inquiry into the effect on agriculture, public health and the ecology of Britain of all chemicals used in agriculture, and that he hoped that the restrictions on the use of cereal seed dressings containing aldrin, dieldrin and heptachlor which he had announced on July 3 would prevent casualties in future among wild birds and mammals. His Department would intensify its survey of wild-life casualties as recommended by the Research Study Group, and consider after next session, with the interests concerned, whether any further action is necessary.

\section{The Commonwealth Scholarship Commission in the} United Kingdom

THE Commonwealth Scholarship Commission was constituted in December 1959 under the Commonwealth Scholarships Act, and in accordance with the proposed arrangements for administering in the United Kingdom the Commonwealth Scholarship and Fellowsinip Plan, recommended by the Commonwealth Education Conference in July 1959 and set forth in the White Paper presented to Parliament. Pending the introduction of the relevant legislation and to facilitate the speedy implementation of the Plan, the Secretary of State for Commonwealth Relations had already appointed an interim committee, with Sir Eric Ashby as chairman, which met three times before the Commission held its first meeting on February 23, 1960, under the Earl of Scarborough as chairman, Sir Eric Ashby being then elected deputy chairman. Confirming the preliminary arrangements made by the interim committee, the Commission endorsed the view that in the first year attention should be concentrated on the selection of Commonwealth Scholars and invitation for senior Commonwealth Fellowships deferred for a year. According to the first annual report of the Commission, up to the end of April 1960, 452 applicants were nominated by overseas agencies from some 5,177 applications received, and from these a Selection Committeo recommended 219 candidates to the Commission, of whom only 178 accepted the offer of scholarships (Cmnd. 1541. Pp. 26. London: H.M.S.O., 1961. 1s. $6 d$. net). Of these, 37 were from India, 17 each from Pakistan and Canada, 16 from Nigeria, 15 from Australia, 10 each from New Zealand and South Africa, and 8 from Hong Kong. Of these again, 74 were in the humanities, 50 in science, 33 in technology and 21 in medicine. The chief considerations in selection were intellectual merit and a realistic and practicable plan of study, but selections were also made so as to ensure that the various parts of the Commonwealth are appropriately represented. Applications have also been invited from candidates in the United Kingdom for awards offered by Canada, Australia, New Zealand, South Africa, Malaya, East Africa and Hong Kong, and scholarships have been offered by Canada to 13 candidates nominated.

\section{Exchange of Students for Technical Experience}

THE fourteenth annual report of the International Association for the Exchange of Students for Technical Experience reports continued growth in 1961, 